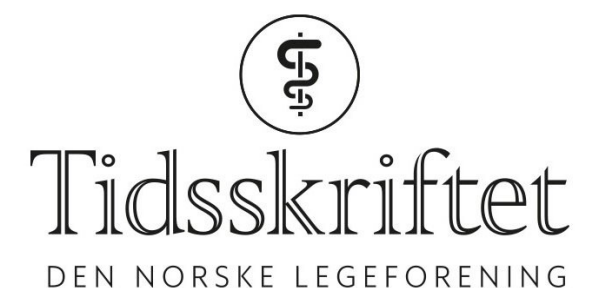

DEN NORSKE LEGEFORENING

\title{
Bivirkninger ved bruk av nyere antikoagulasjonsmidler
}

LEDER

\section{WALEED GHANIMA}

E-post: waleed.ghanima@so-hf.no

Waleed Ghanima er spesialist i indremedisin og i blodsykdommer, forskningssjef og overlege ved Sykehuset Østfold Kalnes og førsteamanuensis ved Avdeling for blodsykdommer, Universitetet i Oslo. Forfatter har fylt ut ICMJE-skjemaet og oppgir følgende interessekonflikter: Han har mottatt stipend og/eller honorar fra Bayer, Pfizer, Amgen og Novartis.

Alvorlige blødninger er de farligste bivirkningene ved bruk av direktevirkende perorale antikoagulantia. Dette viser bivirkningsmeldinger til regionale legemiddelinformasjonssentre.

Siden introduksjonen av direktevirkende perorale antikoagulantia (DOAK) i 2012 har bruken stadig $\varnothing \mathrm{kt}$, og de nye medikamentene har nesten erstattet warfarin ved atrieflimmer og venøs tromboembolisme. Dette skyldes først og fremst at direktevirkende perorale antikoagulantia har raskt innsettende og stabil antikoagulasjonseffekt, at man ikke trenger å måle antikoagulasjonseffekten og at medikamentene har få interaksjoner med andre medikamenter. De gode resultatene fra fase 3-studier hva gjelder sikkerhet og effekt har også vært viktige.

Det er godt kjent at pasienter som deltar i kliniske studier er selektert ut ifra strenge inklusjons- og eksklusjonskriterier. Studiepasienter er av den grunn ofte friskere enn pasienter i vanlig klinisk praksis. Oppfølgingstiden i kliniske studier er som regel relativt kort. Randomiserte kliniske forsøk er derfor ikke tilstrekkelig for å kartlegge sikkerhetsprofilen til nye medikamenter, spesielt ikke sikkerheten ved langtidsbruk, og heller ikke sikkerhetsprofilen i en uselektert populasjon. Viktige kilder til populasjonsbaserte data, såkalte virkelighetsdata, er kvalitetsregistre og nasjonale databaser. I flere land har det vært en stor forskningsinnsats for å skaffe slike data om effekt av og sikkerhet ved direktevirkende perorale antikoagulantia basert på ulike registre (1-3). I registerbaserte studier ser man vanligvis på utfall som allerede er kjent fra før. For direktevirkende perorale antikoagulantia har man for eksempel sett på hyppigheten av slag og blødninger. Funnene fra populasjonsbaserte studier som så langt er publisert om dette, tyder på en lignende effekt- og sikkerhetsprofil som fase 3- studiene har vist (1-3).

Bivirkningsmeldinger er en tredje viktige kilde til sikkerhetsdata, særlig med tanke på sikkerhetsprofilen ved medikamentbruk over lang tid og alvorlige, spesielle og/eller ukjente reaksjoner på legemidler som ikke nødvendigvis blir fanget opp av de nevnte forskningsmetodene. I artikkelen som nå publiseres i Tidsskriftet har Eek og medforfattere gått igjennom databaser fra regionale legemiddelinformasjonssentre (RELIS) i perioden 
2013-15 for å kartlegge meldte bivirkninger for perorale antikoagulasjonsmidler (4). Selv om man ikke kan trekke sikre konklusjoner på bakgrunn av denne rapporten på grunn av de begrensningene som nevnes i artikkelen, er dette et viktig arbeid. Hovedbudskapene er at det ikke har dukket opp nye alvorlige sikkerhetssignaler (bivirkninger), at alvorlige blødninger er de hyppigste og farligste bivirkningene, og at det er økt risiko for alvorlige hendelser hos eldre pasienter med komorbiditet. Et annet viktig budskap er at rapportering av bivirkninger til legemiddelinformasjonssentrene kan gi viktig tilleggsinformasjon til data fra andre kilder.

Eek og medarbeidere viser at dødelige blødninger som regel inntreffer de første månedene etter oppstart av antikoagulasjonsbehandling. Dette understreker viktigheten av grundig klinisk undersøkelse og journalgjennomgang, informasjon til pasientene og kanskje tettere oppfølging særlig de første månedene etter oppstart samt korrigering av reversible risikofaktorer så langt dette lar seg gjøre (5). Blant øvrige bivirkninger ble det notert at hodepine og utslett/kløe hadde blitt registrert hos rivaroksabanbrukere. Disse bivirkningene er omtalt i produktinformasjonen, og det har blitt spekulert i om hodepine forårsakes av vasodilatasjon (6).

Dataene fra RELIS-sentrene kan ikke brukes til å sammenligne sikkerhetsprofilen til de forskjellige typene perorale antikoagulasjonsmidler. Kun pågående randomiserte studier vil kunne gi svar på om det er forskjell mellom medikamentene hva gjelder sikkerhet og effekt. I påvente av stuedieresultatene, og for å øke kunnskapen om direktevirkende perorale antikoagulantia og andre nye legemidler, er det viktig at helsepersonell forsetter å melde fra til RELIS-sentrene og at dataene blir publisert.

\section{LITTERATUR:}

1. Larsen TB, Skjøth F, Kjældgaard JN et al. Effectiveness and safety of rivaroxaban and warfarin in patients with unprovoked venous thromboembolism: a propensity-matched nationwide cohort study. Lancet Haematol 2017; 4: e237 - 44. [PubMed][CrossRef]

2. Halvorsen S, Ghanima W, Fride Tvete I et al. A nationwide registry study to compare bleeding rates in patients with non-valvular fibrillation being prescribed oral anticoagulants. Eur Heart J Cardiovasc Pharmacother 2017;3: 28 -36. [PubMed][CrossRef]

3. Sindet-Pedersen C, Langtved Pallisgaard J, Staerk L et al. Comparative safety and effectiveness of rivaroxaban versus VKAs in patients with venous thromboembolism. A Danish nationwide registrybased study. Thromb Haemost 2017; 117: 1182 - 91. [PubMed][CrossRef]

4. Eek AK, Strøm BO, Bakkehøi G et al. Bivirkninger ved bruk av antikoagulasjonsmidler i 2013-2015. Tidsskr Nor Legeforen 2018; 138: doi: 10.4045/tidsskr.17.0706. [CrossRef]

5. Ghanima W, Atar D, Sandset PM. Nye perorale antikoagulasjonsmidler - en oversikt. Tidsskr Nor Legeforen 2013; 133: 1940 - 5. [PubMed][CrossRef]

6. Mabley J, Scutt G, Lang KJ et al. Rivaroxaban-mediated vascular relaxation as a potential cause of headaches and dizziness. Blood 2015; 126: 2334.

Publisert: 21. august 2018. Tidsskr Nor Legeforen. DOI: 10.4045/tidsskr.18.0566

(C) Tidsskrift for Den norske legeforening 2020. Lastet ned fra tidsskriftet.no 